\title{
A geochemical approach to determining the hydrological regime of wetlands in a volcanic plain, south-eastern Australia
}

\author{
${ }^{[1]}$ Annette B BARTON, ${ }^{[1]}$ Andrew L HERCZEG, ${ }^{[2]}$ Peter G DAHLHAUS, ${ }^{[1]}$ James W COX \\ ${ }^{[1]}$ CSIRO Land and Water and CRC LEME, PMB 2 Glen Osmond SA 5064, Australia, e-mail: \\ annette.barton@csiro.au \\ ${ }^{[2]}$ Deparment of Geology, University of Ballarat, Mt Helen Vic 3350, Australia, e-mail: \\ dahlhaus@netconnect.com.au
}

\begin{abstract}
The Corangamite region in south-eastern Australia contains a large number of lakes and wetlands within an extensive, basaltic plain. To assess the impact of land-use change and groundwater pumping on wetland ecosystems, there is a need to develop a better understanding of their hydrology. This paper describes an approach using groundwater and surface water chemistry and stable isotopes to determine the extent that they are surface or groundwater dominant, and whether they are through-flow or terminal in nature. The ionic ratio $\mathrm{HCO}_{3}{ }^{-} / \mathrm{Cl}^{-}$is higher in surface waters than groundwater, and lakes plot on a continuum between these two water types. Deuterium "excess" $\left(\delta_{\mathrm{xs}}\right.$, where $\left.\delta_{\mathrm{xs}}=\delta^{2} \mathrm{H}-8 * \delta^{18} \mathrm{O}\right)$ reflects the deviation of a given sample from the global meteoric water line, with lower values indicating the increasing influence of evaporation, which in turn reflects longer water residence time (terminal lakes) compared with high $\delta_{\mathrm{xs}}$ lakes that represent through-flow lakes.
\end{abstract}

Keywords: Groundwater-surface water interactions, wetlands, chemistry, isotopes

\section{Introduction}

The Western Plains in the Corangamite region, south-west Victoria, Australia, is characterised by an abundance of freshwater and saline wetlands that are believed to be at least partially dependent on groundwater. The low, undulating country of the Plains, lies between the Central Highlands of the Great Dividing Range to the north and the Otway Ranges to the south (Figure 1). The plain slopes generally toward the west, where there is an outlet to the sea, and features cinder cones, maars, lava shields and the 'stony rise' landscapes.

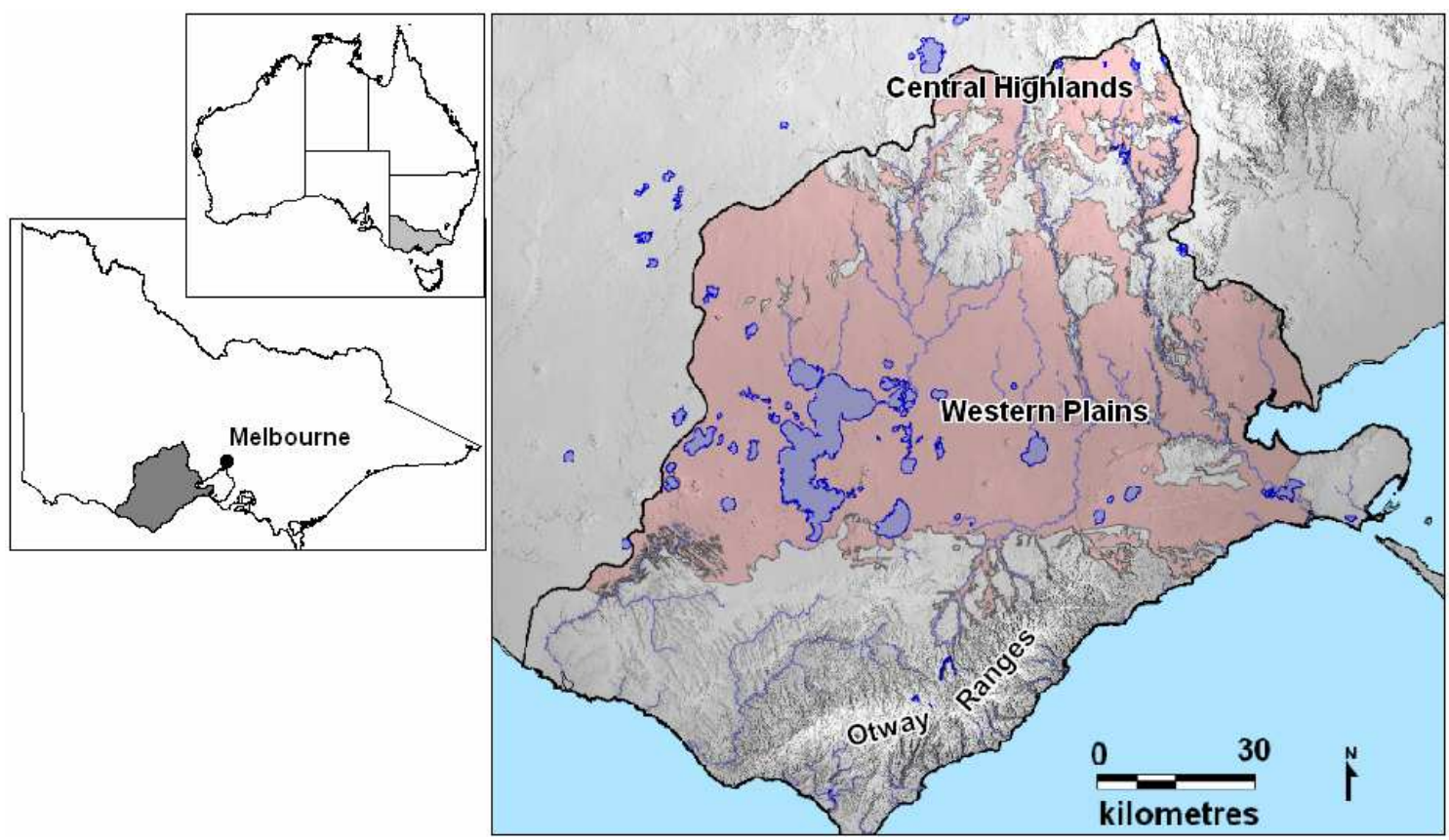

Figure 1. Location maps showing the Corangamite Catchment Management Area, Victoria, Australia and the Western Plains (lakes) region between the Central Highlands and the Otway Ranges. 
The regional groundwater gradient moves from the Central Highlands south towards the plains, and the shallow groundwater moves through gravels, sands and silts of buried palaeochannels, and through the overlying fractured basalt (Cox et al. 2007). On the Western Plains, the shallow groundwater moves under a very low regional gradient through an extensive, thin $(<10 \mathrm{~m})$ confined sand aquifer, underlying the basalt, and through sheets of fractured basalt towards the east and south east. Above the plains, more localised flows occur in the pyroclastic rocks of the eruption points, the fractured rocks of the youngest lava flows and the surficial Quaternary alluvial and aeolian sediments.

Low topographic gradients have resulted in sparsely distributed linear drainage channels usually terminating in shallow lakes. The lakes have a variety of landforms, such as crater lakes, maars, sag ponds, lakes formed in the depressions of the volcanic plains, lakes formed behind basalt barriers, and areas with impounded drainage. Some of the larger lakes are terminal lakes for both surface water and groundwater flow, whereas others are terminal for surface water flow but throughflow for groundwater (Coram et al. 1998). Smaller lakes, especially those formed in volcanic craters and maars are groundwater sinks with little surface water input.

Annual rainfall varies from over $1000 \mathrm{~mm}$ in the elevated areas of the Central Highlands to less than $500 \mathrm{~mm}$ on the eastern edge of the Western Plains. The vast majority of the volcanic plains in the Corangamite region receive between 600 and $700 \mathrm{~mm}$ annually, with winter and spring as the dominant wet seasons. In times of abnormally high rainfalls, the lakes have been known to fill and merge, flooding large tracts of farmland. To manage the flooding, two major drainage channels were built in the 1950s and 60s to drain the larger lakes into the river system to the west.

Many of the more than 1400 declared wetlands of the Corangamite region are recognised as being of international ecological value, in particular the twenty-seven Ramsar listed wetlands which include Lake Corangamite, Australia's largest, inland, permanent, saline lake. Sustained rises in lake salinity levels over the last 50 years has focussed attention on the impacts of human activities on wetland health (Williams 1995, 1999; Adler \& Lawrence 2004; Nicholson et al. 2006). Since the commencement of European settlement 160 years ago, widespread land-use and water-use changes have occurred. The extensive cultivation of pastures and crops has involved the clearing of natural vegetation and irrigation using groundwater resources; and flood mitigation/drainage works has brought hydrological changes through the diversion of surface water flows from the lakes.

In order to assess the impact of groundwater pumping and changes to surface flow systems on the wetlands, research has been instigated to quantify the groundwater and surface water inputs to the lakes and hence improve understanding of their sensitivity to changes in groundwater recharge and discharge. In this paper the groundwater and surface water chemistry, including stable isotopes, is presented and a method described to distinguish between surface water, groundwater and evaporation dominated lakes.

\section{Approach and Method}

A reconnaissance sampling of lake surface waters was undertaken with the aim of investigating a method for the rapid assessment of the groundwater dependence of the lakes of the region. It was hypothesised that a combination of isotopic and chemical parameters could be used to assess the groundwater dependence of the wetlands. The approach taken was to firstly obtain an understanding of the types of wetlands present and then undertake further, more in-depth research, into a few select "typical" lakes.

Sampling of the lake surface waters commenced in July 2006 and is still on-going. Forty-six lakes were visited on the initial reconnaissance field trip, when it was ascertained that only a small fraction (around 2\%) of the more that 1400 declared lakes and wetlands in the region (Wetland_1994) still contained some water. Like much of Australia, this area has been experiencing a prolonged period of below average rainfall, and in 2006 the 10 year rainfall average was at a record low (BOM 2007). 
Samples were obtained from 24 wetlands on the first sampling trip (Figure 2). Electrical conductivity (EC), $\mathrm{pH}$, dissolved oxygen (DO) and temperature were measured on site using a calibrated field kit. The surface water grab samples were subsequently analysed in the CSIRO laboratories in Adelaide, South Australia, for chemistry and stable isotopes of water.

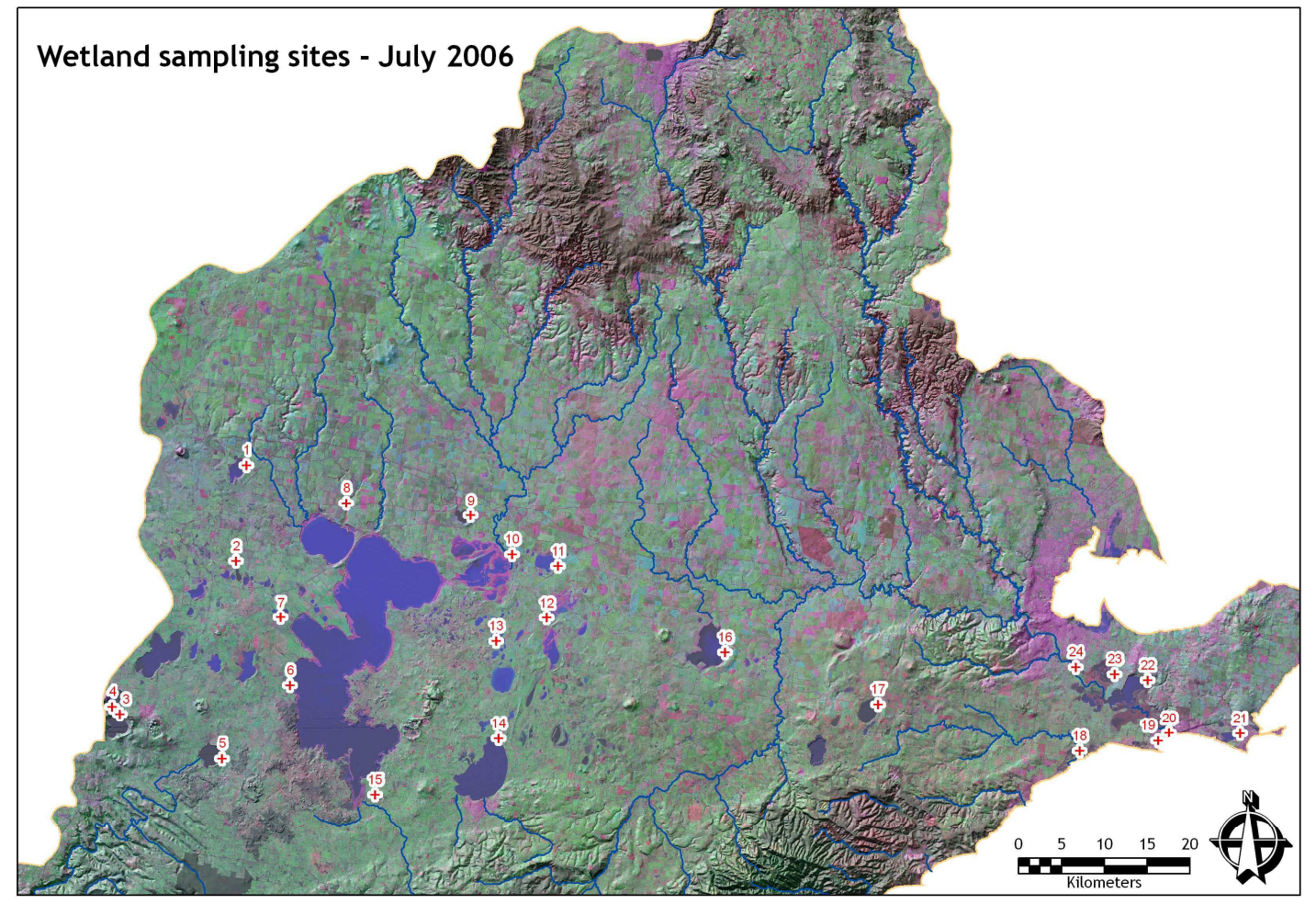

Figure 2. Location of lake sampling sites within the Western plains. On-going (fortnightly) sampling is continuing for West Basin (No. 15), Lake Colac (No. 14) and Weering Lake (No. 11).

The lakes were revisited three months later, in October 2006, and a second set of samples were collected. On this occasion it was found that some of the lakes previously sampled had dried out and could not be sampled. Since January 2007 a fortnightly sampling program has been maintained for three of the lakes (West Basin, Lake Colac and Weering Lake).

\section{Results}

\subsection{Chemistry}

The salinity of the lakes sampled range over nearly three orders of magnitude (TDS of 520 to $\sim 310,000 \mathrm{mg} / \mathrm{L}$ ) and are alkaline, with $\mathrm{pH}$ 's between 7.8 and 9.9. Dissolved solutes of the Corangamite lakes are in general dominated by $\mathrm{Na}^{+}$and $\mathrm{Cl}^{-}$ions, although $\mathrm{HCO}_{3}^{-}$makes up a significant fraction of anions at the lower salinity (Fig. 3). The dominance of $\mathrm{Na}^{+}$and $\mathrm{Cl}^{-}$over the other ions increases linearly as a function of TDS. Calcium and $\mathrm{HCO}_{3}{ }^{-}$remain low throughout the entire salinity range indicating control of these dissolved ions through precipitation of carbonate minerals. The low salinity waters (TDS $<2,500 \mathrm{mg} / \mathrm{L}$ ) have higher proportion of $\mathrm{HCO}_{3}{ }^{-}$and alkaline earth ions $\left(\mathrm{Mg}^{2+}\right.$ and $\left.\mathrm{Ca}^{2+}\right)$ relative to other ions than the more saline waters $(>2,500 \mathrm{mg} / \mathrm{L})$ indicating that these lakes probably have a significant fraction of their solutes derived from mineral weathering. 

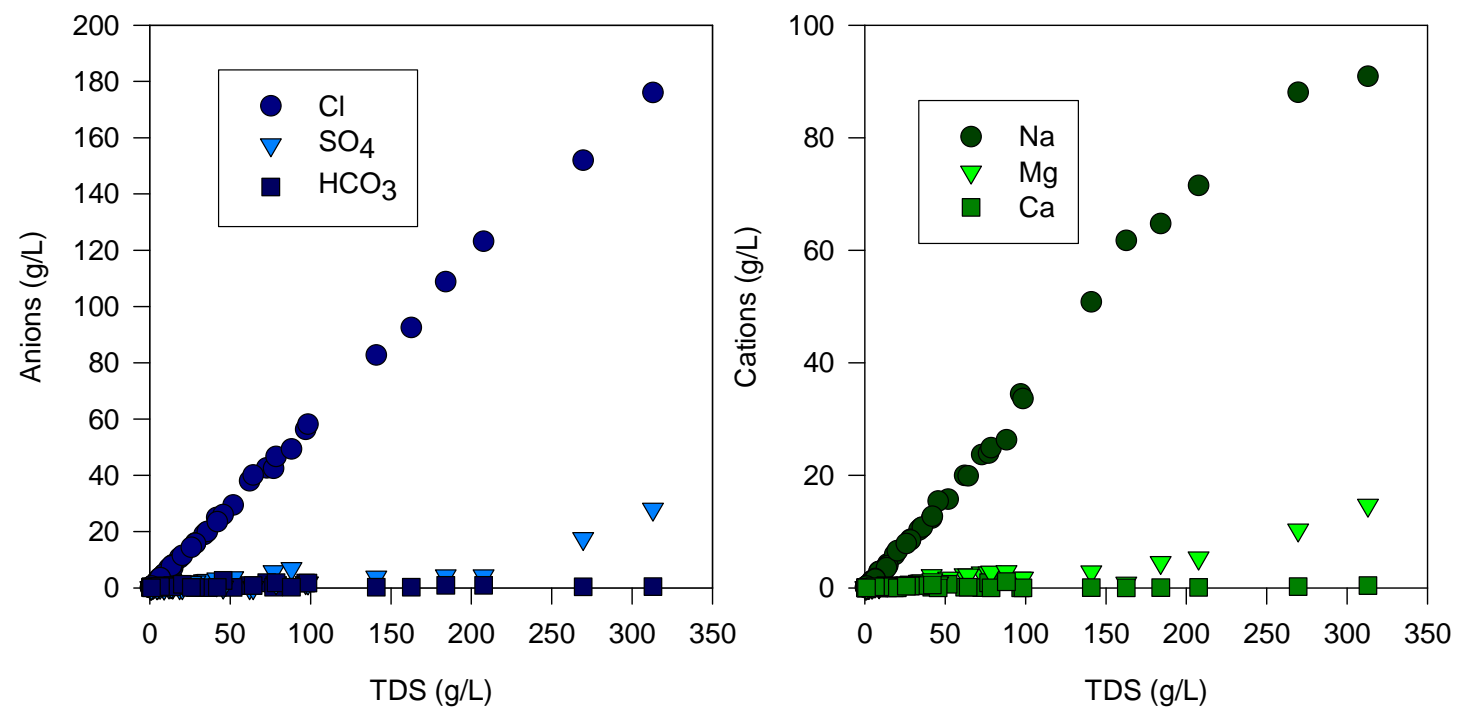

Figure 3. Plots showing lake water anions and cations as a function of TDS

The composition of the more saline lake waters (TDS > 2,500 mg/L) is similar to that of seawater and the more saline groundwaters. Therefore, it is believed that the source of most of the dissolved ions for the both the lakes and groundwaters are derived from marine aerosols deposited by rainfall. The ratio of $\mathrm{Cl}^{-} / \mathrm{Br}^{-}$in all lakes are slightly higher than that of seawater (290) which demonstrates the dominance of the marine origin of $\mathrm{Cl}^{-}$and, by inference, $\mathrm{Na}^{+}$. The linear relationship for the majority of the ions points to evaporation processes as the dominant control of salinity levels in the lakes.

\subsection{Stable Isotopes}

The stable isotopes of water $\left({ }^{2} \mathrm{H} /{ }^{1} \mathrm{H}\right.$ and $\left.{ }^{18} \mathrm{O} /{ }^{16} \mathrm{O}\right)$ are considered to be one of the most useful tracers in establishing a lake water balance, particularly with respect to the subsurface components (Rozanski et al. 2000). Evaporation leads to increases in the ratio of ${ }^{2} \mathrm{H} /{ }^{1} \mathrm{H}$ and ${ }^{18} \mathrm{O} /{ }^{16} \mathrm{O}$ of residual waters with the isotopic concentrations evolving linearly in $\delta^{2} \mathrm{H}-\delta^{18} \mathrm{O}$ space. The degree of evaporative enrichment is dependent on atmospheric relative humidity over the lake and the surface water temperature.

Results for the stable isotopes of water for the two sets of lake samples collected are shown in $\delta^{2} \mathrm{H}$ $\delta^{18} \mathrm{O}$ space in Figure 4. Those lakes that lie further to the right along the trend line have undergone a greater degree of evaporation relative to the rate of inflow. The lake water balance can be simply represented by a balance between the relatively light isotopic composition of inflow, and the tendency of evaporation to remove the lighter isotope preferentially to the heavier isotope thereby enriching the remaining water in the heavier isotope. In a semi-quantitative way the lakes increase in residence time (Residence time $=$ total volume/total input rate) the further they lie to the right of isotopic trend line. 


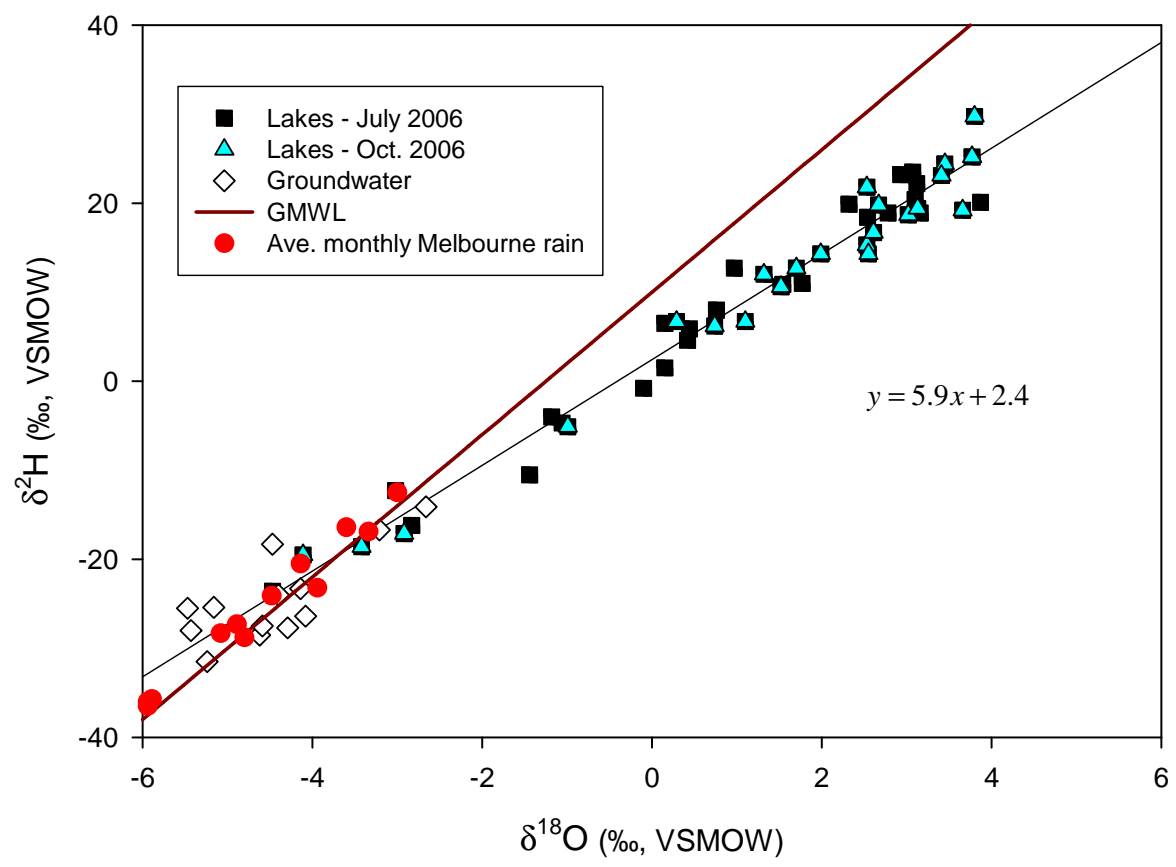

Figure 4. Plot of lake and groundwater stable isotopes of water showing similarities in the isotopic signatures of groundwater and rainwater and the trend line for the lakes.

The data have been presented together with isotope values for groundwater sampled from shallow $(<25 \mathrm{~m})$ bores in the vicinity of the lakes as well as monthly isotopic data for Melbourne rain. Groundwater samples tend to plot within the domain of the average monthly values for Melbourne rainfall. As the isotopic composition of groundwater is virtually indistinguishable from that for rainfall, the evaporation trend observed for the lakes would be almost identical for the two types of inflow, viz groundwater and surface water.

\section{Discussion}

\subsection{A preliminary evaluation of lake types}

In plotting the ratio of $\mathrm{HCO}_{3}{ }^{-} / \mathrm{Cl}^{-}$as a function of TDS (Figure 5) it can be seen that the ratio ranges over some three orders of magnitude with an overall decrease with increasing TDS. The freshest lakes (TDS $<2,500 \mathrm{mg} / \mathrm{L}$ ) tend to have higher $\mathrm{HCO}_{3}{ }^{-} / \mathrm{Cl}^{-}$which is indicative of surface and inter-flow runoff components which tend to have a higher component of $\mathrm{HCO}_{3}{ }^{-}$due to mineral-solution reactions that produce $\mathrm{HCO}_{3}{ }^{-}$as a by-product. Lakes with salinities $>2,500 \mathrm{mg} / \mathrm{L}$ show $\mathrm{HCO}_{3}{ }^{-} / \mathrm{Cl}^{-}<0.08$ reflecting a higher saline groundwater component to the water balance. Therefore one may be able to separate the lakes into two groups: low salinity $(<2,500 \mathrm{mg} / \mathrm{L})$ and high $\mathrm{HCO}_{3}{ }^{-} / \mathrm{Cl}^{-}(>0.08)$ that are surface water and inter-flow dominated; and higher salinity $(>2,500 \mathrm{mg} / \mathrm{L})$ and low $\mathrm{HCO}_{3}{ }^{-} / \mathrm{Cl}^{-}(<0.01)$ that are groundwater dominated. The intermediate group may represent mixing between the two end-members.

While $\mathrm{HCO}_{3}{ }^{-}$is not conservative over the entire salinity range, the $\mathrm{HCO}_{3}{ }^{-} / \mathrm{Cl}^{-}$values of groundwater samples are generally low due to evapo-transpiration and precipitation of carbonate within the soil zone. On the other hand, the short residence time of surface water runoff and interflow in the zone where $\mathrm{CO}_{2}$ is produced, and consequent weathering of volcanic minerals results in much higher $\mathrm{HCO}_{3}^{-}$ relative to $\mathrm{Cl}^{-}$. This approach is more sensitive than using salinity alone which cannot distinguish between groundwater fed systems and those dominated by surface water within a moderate degree of evaporation. 


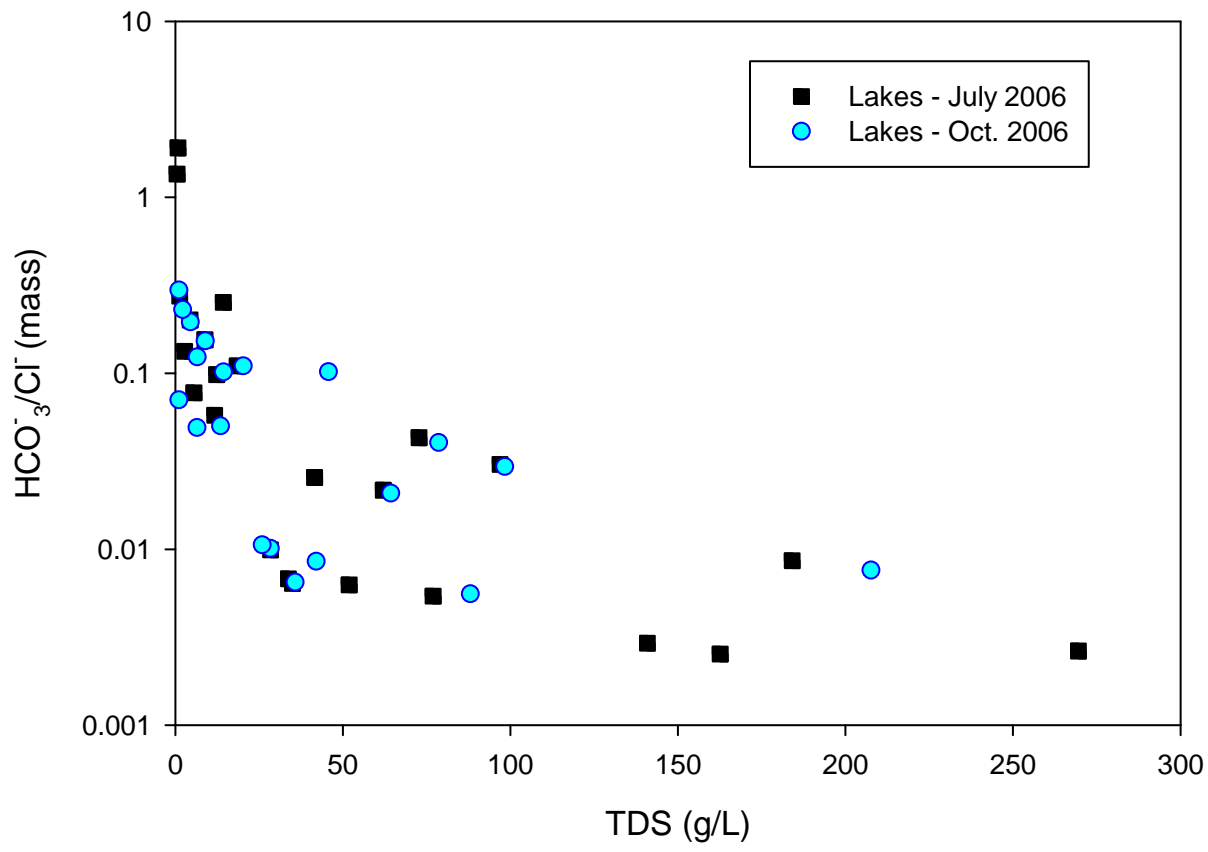

Figure $5 . \mathrm{HCO}_{3}{ }^{-} / \mathrm{Cl}^{-}$as a function of TDS

Accepting the $\mathrm{HCO}_{3}{ }^{-} / \mathrm{Cl}^{-}$ratio as an indicator of surface water and groundwater dominance, we can further categorise the lakes by plotting the $\mathrm{HCO}_{3}{ }^{-} / \mathrm{Cl}^{-}$ratio with respect to the deuterium excess (Figure 6).

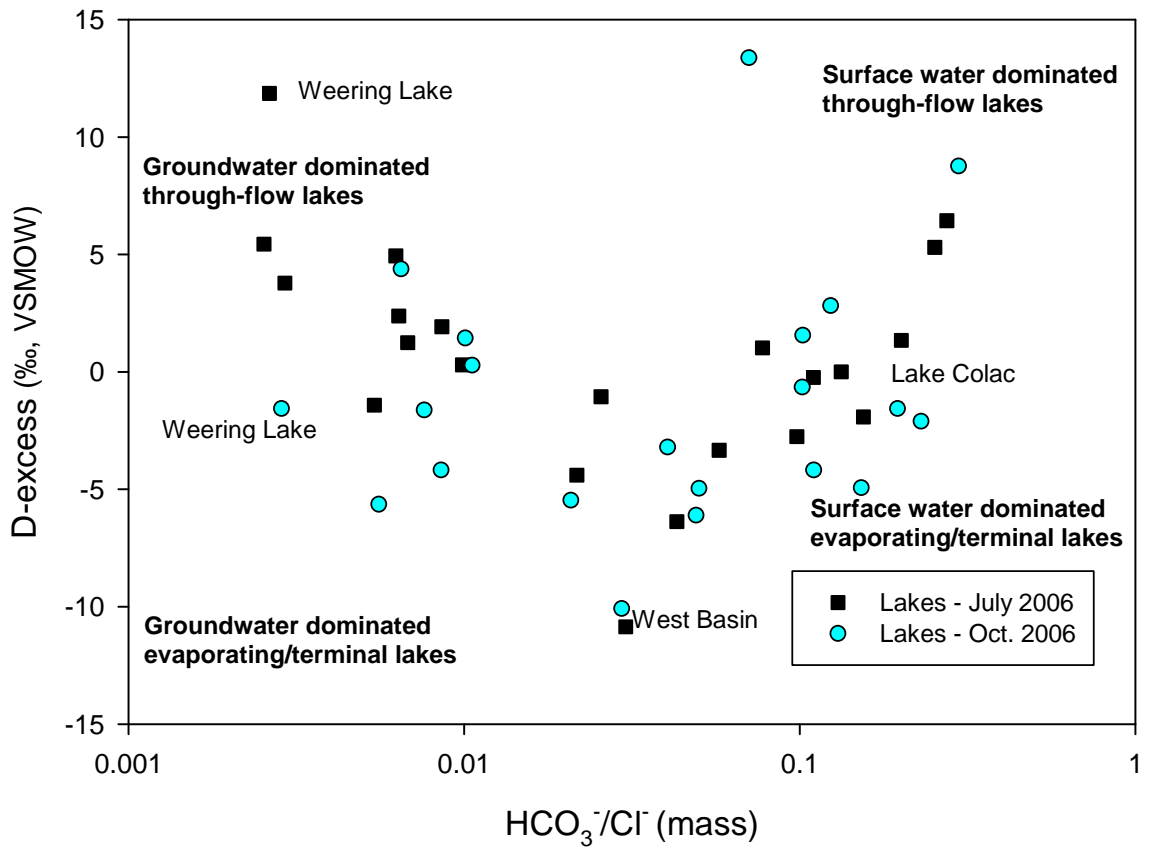

Figure 6. Deuterium "excess" versus $\mathrm{HCO}_{3}{ }^{-} / \mathrm{Cl}^{-}$ 
The deuterium excess, $\delta_{\mathrm{xs}}=\delta^{2} \mathrm{H}-8^{*} \delta^{18} \mathrm{O}$, reflects the deviation of a given sample from the meteoric water line and hence is an indicator of residence time and a measure of evaporation. Lower values indicate the increasing influence of evaporation. Most of the groundwater samples have a deuterium excess of between $7-12$, which is slightly less than the local meteoric water values of 13 , while the lake waters have a $\delta_{\mathrm{xs}}$ generally between 5 and -5 . If there was a large flow-through of groundwater, then the $\delta_{\mathrm{xs}}$ would approach that of groundwater $\delta_{\mathrm{xs}}$ values. Hence, plotting the $\delta_{\mathrm{xs}}$ values data as a function of $\mathrm{HCO}_{3}{ }^{-} / \mathrm{Cl}^{-}$provides a means of at least qualitatively distinguishing between the water source of the lakes - surface water or groundwater - and whether they are through-flow or have long residence times. Four end-members can be defined:

1. groundwater dominated, through-flow (high $\delta_{\mathrm{xs}}$, low $\mathrm{HCO}_{3}{ }^{-} / \mathrm{Cl}^{-}$);

2. groundwater dominated, long-residence (low $\delta_{\mathrm{xs}}$, low $\left.\mathrm{HCO}_{3}{ }^{-} / \mathrm{Cl}^{-}\right)$;

3. surface water dominated, through-flow (high $\delta_{\mathrm{xs}}$, high $\mathrm{HCO}_{3}{ }^{-} / \mathrm{Cl}^{-}$);

4. surface water dominated, long-residence (low $\delta_{\mathrm{xs}}$, high $\mathrm{HCO}_{3}{ }^{-} / \mathrm{Cl}^{-}$).

These 4 types have been illustrated in Figure 7.

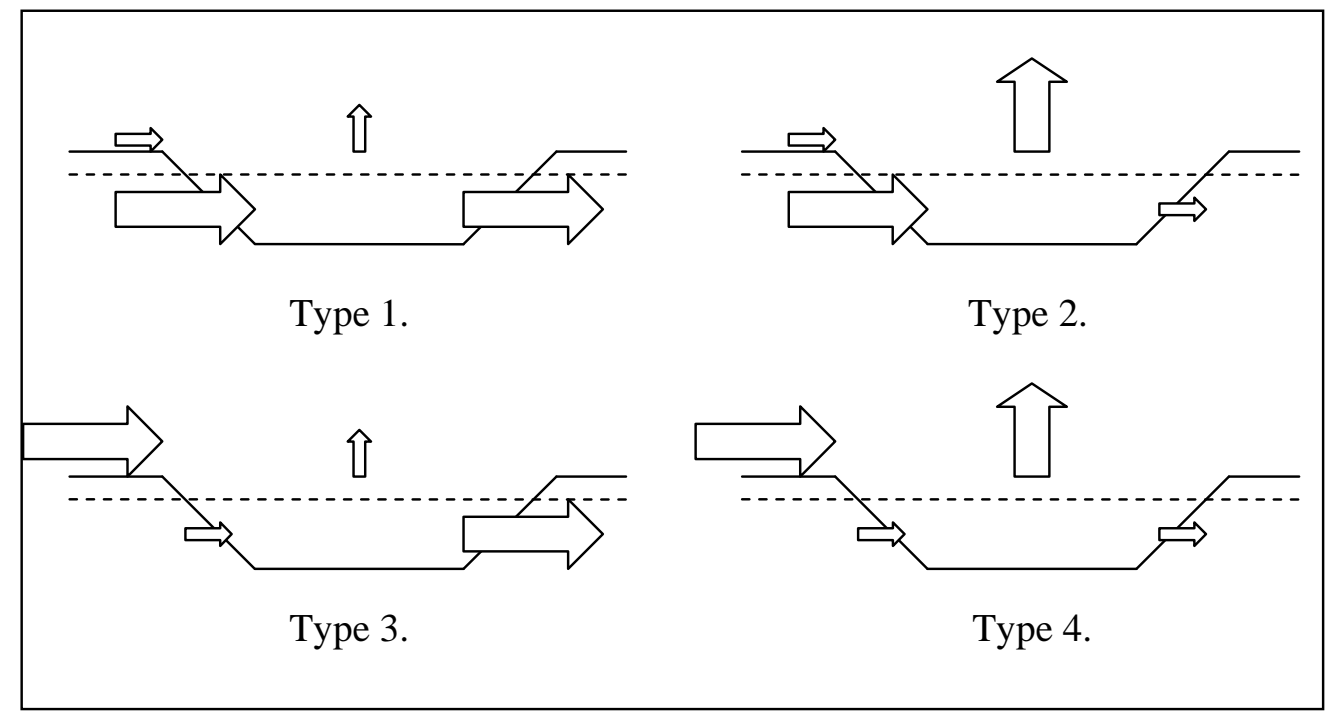

Figure 7. Conceptual representation of the four hydrological lake types

As lakes evolve into the terminal type (low $\delta_{\mathrm{xs}}$ ) the differentiation between groundwater and surface water dominance is not possible due to the mineral precipitation controls on $\mathrm{HCO}_{3}{ }^{-}$concentration.

Most lakes do not fall clearly within one type lie along a continuum between two or more groups. Furthermore variation in hydrologic condition (e.g. rising or falling groundwater tables, or changes in surface runoff) may result in a change to the lake's status.

\subsection{Method assessment}

This method provides an initial classification of the lakes which is not possible otherwise without detailed gauging of surface runoff and installing groundwater bores to obtain quantitative description of the groundwater and surface water inputs. Known physical and hydro-geological aspects of specific lakes can be compared with where the lakes lie on the $\mathrm{HCO}_{3} / \mathrm{Cl}^{-}$versus $\delta_{\mathrm{xs}}$ plot, as a preliminary method of validation. West Basin, for example, is a crater lake with little surface water catchment and no outlet. It is logical that that this lake falls in the region of an evaporating or terminal lake $\left(\delta_{\mathrm{xs}}=-\right.$ 10.9) with high groundwater dependence $\left(\mathrm{HCO}_{3}{ }^{-} / \mathrm{Cl}^{-}=0.03\right)$. Lake Colac, on the other hand, is a larger, shallower, lake with tributaries on the south and an outlet to its north. It plots $\left(\mathrm{HCO}_{3}{ }^{-} / \mathrm{Cl}^{-}=0.2\right.$, $\left.\delta_{\mathrm{xs}}=1.3 \&-1.6\right)$ as a surface water dominated lake and between the terminal and through-flow types. 
This is consistent with the period of sampling when the lake was experiencing a prolonged dry period with diminishing surface flows. A third lake is Weering Lake which is essentially a shallow depression in the flat landscape with no defined inlet and outlet. The $\mathrm{HCO}_{3}{ }^{-} / \mathrm{Cl}^{-}$ratio for this lake is very low, 0.003 , indicating a groundwater dominated lake. Between the first and second sampling events $\delta_{\mathrm{xs}}$ varied markedly between 11.9 and -1.6. This possibly indicates a decoupling of the lake from the groundwater table as it continued to dry out.

Fortnightly sampling of the three aforementioned lakes (West Basin, Lake Colac and Weering Lake) is being undertaken and groundwater levels in the vicinity of these lakes are being monitored. This data will provide a basis to estimate the water balance of the lakes and make comparison with the geochemical data. The period in which the sampling discussed in this paper was undertaken was one of the driest on record and came at the end of an historic 10 year average low (BOM 2007). The ongoing drying of the lakes points to the fact that inflows, either of groundwater or surface water, have been limited.

\section{Conclusions}

A method is described that uses water chemistry and stable isotope data to distinguish between the dominant water source (groundwater or surface water) and flow regime (through-flow or evaporating/terminal) of a series of wetlands in a basaltic plain of SE Australia. High $\mathrm{HCO}_{3}{ }^{-} / \mathrm{Cl}^{-}$are indicative of surface water dominance, while low $\mathrm{HCO}_{3}{ }^{-} / \mathrm{Cl}^{-}$reflect groundwater dominance, Deuterium "excess" $\left(\delta_{\mathrm{xs}}\right.$, where $\left.\delta_{\mathrm{xs}}=\delta^{2} \mathrm{H}-8^{*} \delta^{18} \mathrm{O}\right)$ as an indicator of lake water residence time, with low values indicating terminal or evaporation dominated lakes. The wetlands lie on a continuum between four end member lake types, viz: groundwater dominated, through-flow; groundwater dominated, long-residence time; surface water dominated, through-flow; and surface water dominated, long-residence time.

Acknowledgements This project is funded through a National Action Plan for Salinity and Water Quality grant administered by the Corangamite Catchment Management Authority. We thank Phil Davies and John Dighton, CSIRO and Bob Smith, University of Ballarat, for assistance on this project, and Sebastien Lamontagne, CSIRO for reviewing the paper.

\section{References}

Adler R and Lawrence CR (2004) The drying of the Red Rocks Lakes Complex, Australia and its implications for groundwater management. Paper presented at the XXXIII Congress of the International Association of Hydrogeologist, Zacatecas, Mexico.

BOM (2007) Rainfall data for weather station number 090147 (Colac Shire Office). Australian Bureau of Meteorology, http://www.bom.gov.au/silo/ "patched point data" set cited November 2006.

Coram JE, Weaver TR, Lawrence CR (1998) Groundwater - surface water interactions around shallow lakes of the Western District Plains, Victoria, Australia. Paper presented at the International Groundwater Conference of the International Association of Hydrogeologists, University of Melbourne, Melbourne, Australia, 8-13 February 1998.

Cox J, Dahlhaus P, Herczeg A, Crosbie R, Davies P and Dighton J (2007) Defining groundwater flow systems on the Volcanic Plains to accurately assess the risks of salinity and impacts of changed landuse. Final report to the Corangamite Catchment Managment Authority, Draft edn, CSIRO Land and Water, Urrbrae, SA.

Nicholson C, Dahlhaus PG, Anderson G, Kelliher CK and Stephens M (2006) Corangamite salinity action plan: 2005 - 2008. Corangamite Catchment Management Authority, Colac, Victoria.

Rozanski K, Froehlich K, Mook WG (2000) Surface Water. Technical Documents in Hydrology, UNESCO, Paris.

Wetland_1994 (n.d.) Victorian Wetland Environments and Extent - up to 1994. Corporate Geospatial Data Library, Department of Sustainability and Environment, Victoria, Australia.

Williams WD (1995) Lake Corangamite, Australia, a permanent saline lake: conservation and management issues. Lakes \& Reservoirs: Research and Management Vol. 1:55-64.

Williams, W.D. (1999) Conservation of wetlands in drylands: a key global issue. Aquatic Conservation: Marine and Freshwater Ecosystems Vol. 9(6): 517-22. 